\title{
SIDESWAY MAGNIFICATION FACTORS FOR STEEL MOMENT FRAMES WITH VARIOUS TYPES OF COLUMN BASES
}

\author{
J. Kent Hsiao \\ Associate Professor, Department of Civil and Environmental Engineering, \\ Southern Illinois University Carbondale, Carbondale, IL, USA \\ E-mail:hsiao@engr.siu.edu
}

Received: 26 June 2012; Revised: 12 July 2013; Accepted: 17 July 2013

\begin{abstract}
The sidesway magnification factor was introduced to the design of columns in moment frames subjected to the P- $\Delta$ effect. Three approaches for the computation of the sidesway magnification factor, namely, the column-lateral-buckling-strength approach, the story-lateral-stiffness approach, and the modified-story-lateral-stiffness approach, were suggested by the 2005 AISC Specification for Structural Steel Buildings, the ASCE/SEI 7-10 Minimum Design Loads for Buildings and Other Structures, and the 2010 AISC Specification for Structural Steel Buildings, respectively. This paper evaluates the sidesway magnification factors derived from the aforementioned three approaches for four different column base conditions, namely, ideal fixed-, ideal pinned-, practical fixed-, and practical pinned-base conditions. The results of the study conducted in this paper are that (1) if only the flexural deflections are considered in the frame analysis, the sidesway magnification factor derived from the modified story-lateral-stiffness approach closely agrees with that derived from the column-lateral-buckling-strength approach and (2) if the flexural deflections, as well as the shear and axial deformations, are considered in the frame analysis, the sidesway magnification factor derived from the story-lateral-stiffness approach closely agrees with that derived from the column-lateral-buckling-strength approach.
\end{abstract}

Keywords: Deflection, Effective length, Lateral forces, Sidesway, Steel columns, Steel frames

\section{INTRODUCTION}

Many methods have been introduced to the P- $\Delta$ analysis of columns in moment frames. These methods include the amplification factor method, the direct method, the iterative method, the negative property fictitious member methods, and the second-order computer program method. The amplification factor method is a rapid, but very approximate method while the direct method gives accurate results for low- or medium-rise rigid frames [1]. Both the amplification factor method and the direct method are commonly used by structural engineers for the computation of the sidesway magnification factor for the design of columns in steel moment frames subjected to the P- $\Delta$ effect. The amplification factor method involves the computation of the lateral buckling strength of the columns in the story being considered; this method was suggested by the 2005 AISC Specification for Structural Steel Buildings [2]. The direct method involves the computation of the lateral stiffness of the story being considered; this method was suggested by the 2005 AISC Specification for Structural Steel Buildings, the ASCE/SEI 7-10 Minimum Design Loads for Buildings and Other Structures [3], and the 2010 AISC Specification for Structural Steel Buildings [4]. The following is a summary of the approaches for the computation of the sidesway magnification factor caused by the P- $\Delta$ effects suggested by the 2005 AISC, ASCE/SEI 7-10, and 2010 AISC, respectively.

The 2005 AISC Specification for Structural Steel Buildings suggests the following two approaches for the computation of the sidesway amplifier values $\left(B_{2}\right)$ for the design of columns in moment frames subjected to the P- $\Delta$ effect: 


$$
\begin{gathered}
B_{2}=\frac{1}{1-\frac{\alpha \sum P_{n t}}{\sum \frac{\pi^{2} E I}{\left(K_{2} L\right)^{2}}}} \geq 1 \\
B_{2}=\frac{1}{1-\frac{\alpha \sum P_{n t}}{R_{M} \frac{\sum H L}{\Delta_{H}}}} \geq 1
\end{gathered}
$$

where $\alpha=1.00$ for the Load and Resistance Factor Design (LRFD); $\sum P_{n t}=$ the total vertical load supported by the story; $E=$ the modulus of elasticity of steel, 29,000 ksi (200 $000 \mathrm{MPa}) ; I=$ the moment of inertia in the plane of bending; $K_{2}=$ the effective length factor in the plane of bending, based on sidesway buckling; $L=$ the story height; $R_{M}=0.85$ for moment-frame systems; $\sum H=$ the story shear produced by the lateral forces used to compute $\Delta_{H}$; and $\Delta_{H}=$ the first-order interstory drift resulting from lateral forces.

The first approach (Eq. 1) uses the same method as the aforementioned "amplification factor method," which involves the computation of the Euler load of the column [5] and the elastic story sidesway buckling resistance. The effective length factor $\left(K_{2}\right)$ presented in Eq. 1 can be determined by using the "Alignment Chart-Sidesway Uninhibited (Moment Frame)" presented in the 2005 AISC Specification for Structural Steel Buildings. The second approach (Eq. 2) uses the same method as the aforementioned "direct method," which involves the elastic analysis of the first-order interstory drifts due to lateral forces $[1,6]$.

The ASCE/SEI 7-10 Minimum Design Loads for Buildings and Other Structures suggests the following approach for the computation of the sidesway magnification factor for the design of columns in moment frames subjected to the P- $\Delta$ effect:

$$
\text { magnification factor }=\frac{1}{1-\frac{p_{x}}{\left(\frac{V_{x} h_{s x}}{\delta_{x e}-\delta_{(x-1) e}}\right)}}
$$

where $P_{x}=$ the total vertical design load at and above level $x ; V_{x}=$ the shear force acting between levels $x$ and $x-1 ; h_{s x}=$ the story height below level $x ; \delta_{x e}=$ the displacement at level $x$ by a first-order elastic analysis; and $\delta_{(x-1) e}=$ the displacement at level $x$ - 1 by a first-order elastic analysis.

This approach (Eq. 3) uses the same method as the aforementioned "direct method," which involves the computation of the first-order interstory drifts due to lateral forces. Note that the only difference between Eqs. 2 and 3 is that Eq. 2 considers the lateral stiffness modification coefficient, $R_{M}$, while Eq. 3 does not.

The 2010 AISC Specification for Structural Steel Buildings suggests the following approach (Eq. 4) for the computation of the sidesway amplifier value $\left(B_{2}\right)$ for the design of columns in moment frames subjected to the P- $\Delta$ effect: 


$$
B_{2}=\frac{1}{1-\frac{\alpha P_{\text {story }}}{R_{M} \frac{H L}{\Delta_{H}}}} \geq 1
$$

where $\alpha=1.00$ for the Load and Resistance Factor Design (LRFD); $P_{\text {story }}=$ the total vertical load supported by the story; $R_{M}=1-0.15\left(P_{m f} / P_{\text {story }}\right) ; \quad P_{m f}=$ the total vertical load in columns in the story that are part of moment frames; $L=$ the story height; $H=$ the story shear produced by the lateral forces used to compute $\Delta_{H}$; and $\Delta_{H}=$ the first-order interstory drift resulting from lateral forces.

Note that for a building in which lateral stiffness is provided entirely by moment frames, $P_{m f}=P_{\text {story }}$, which in turn results in $R_{M}=0.85$. Therefore, Eqs. 2 and 4 are identical.

\section{EFFECTIVE LENGTH FACTORS FOR COLUMNS IN SWAY FRAMES}

The effective length factor $(K)$ for columns in a sway frame can be determined by using the alignment chart for uninhibited sidesway (presented in Chapter C - Stability Analysis and Design in the 2005 AISC Specification for Structural Steel Buildings) or by using the following equation [2]:

$$
\frac{G_{A} G_{B}(\pi / K)^{2}-36}{6\left(G_{A}+G_{B}\right)}-\frac{(\pi / K)}{\tan (\pi / K)}=0
$$

where $G=$ the restraint factor at the column end (the subscripts A and B refer to the joints at the top and bottom of the column being considered $)=\sum\left(I_{c} / L_{c}\right) / \sum\left(I_{b} / L_{b}\right)$

The approximate $K$ value can be obtained by using the following equation [7]:

$$
K=\sqrt{\frac{1.6 G_{A} G_{B}+4.0\left(G_{A}+G_{B}\right)+7.5}{G_{A}+G_{B}+7.5}}
$$

For a column with a complete fixity at its base, $G_{B}=0$, Eq. 5 becomes

$$
K=\sqrt{\frac{4.0 G_{A}+7.5}{G_{A}+7.5}}
$$

For a column with a true friction-free pinned base, $G_{B}=\infty$, Eq. 5 becomes

$$
K=\sqrt{1.6 G_{A}+4.0}
$$

The 2005 AISC Specification, however, suggests that if the column end is rigidly attached to a properly designed footing, $G_{B}$ may be taken as 1.0. Smaller values may be used if justified by analysis. The reader is referred to the AISC "Steel Design Guide 1 - Base Plate and Anchor Rod Design" [8] for the design of column base plates with moments. The AISC Specification also suggests that if the column base is not rigidly connected to a footing or foundation, $G_{B}$ may be taken as 10 for practical designs. $G_{B}$ is theoretically infinity if the column base is designed as a true friction-free pin. 


\section{STORY DRIFTS OF MOMENT FRAMES UNDER LATERAL LOADS}

Referring to the frame shown in Figure 1, the column sizes are identical and both columns have a fixed base connection. The horizontal load, $\mathrm{H}$, is acting at joint 1 . Using the stiffness method, the following equation can be derived [9]:

$$
\left[\begin{array}{ccc}
2\left(k_{1-3}+k_{1-2}\right) & k_{1-2} & 3 k_{1-3} \\
k_{1-2} & 2\left(k_{1-2}+k_{2-4}\right) & 3 k_{2-4} \\
3 k_{1-3} & 3 k_{2-4} & 6\left(k_{1-3}+k_{2-4}\right)
\end{array}\right]\left[\begin{array}{c}
\theta_{1} \\
\theta_{2} \\
-R
\end{array}\right]=\left[\begin{array}{c}
0 \\
0 \\
H L_{c}
\end{array}\right]
$$

where $k_{i-j}=2 E_{i-j} I_{i-j} / L_{i-j} ; \theta_{i}=$ rotation at joint $i ; R=\Delta_{H} / L_{c}$.

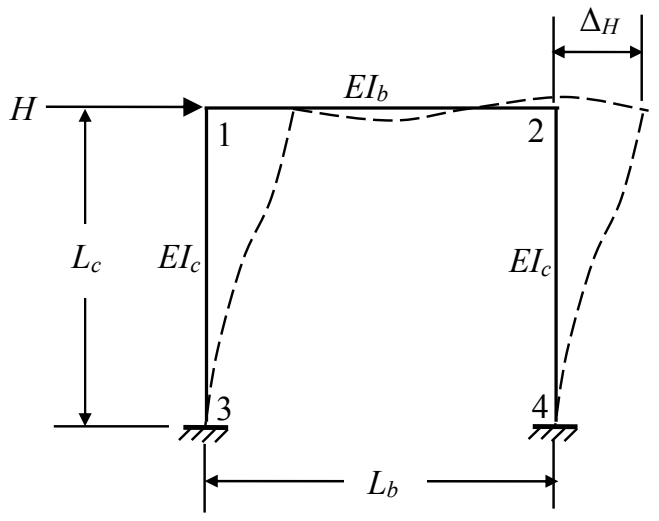

\section{Notes:}

$I_{c}=$ moment of inertia of column

$I_{b}=$ moment of inertia of beam

$L_{c}=$ column length

$L_{b}=$ beam length

$E=$ modulus of elasticity, constant for all members

$\Delta_{H}=$ story drift resulting from lateral force $H$

Figure 1. Typical Moment Frame with Ideal Fixed-Base Connections

Since the sizes and lengths of the two columns are identical, $k_{1-3}=k_{2-4}=2 E I_{c} / L_{c} . \quad$ Setting $\lambda=\left(I_{b} / L_{b}\right)$ $/\left(I_{c} / L_{c}\right)$, Eq. 8 can be rewritten as

$$
\frac{2 E I_{c}}{L_{c}}\left[\begin{array}{ccc}
2(\lambda+1) & \lambda & 3 \\
\lambda & 2(\lambda+1) & 3 \\
3 & 3 & 12
\end{array}\right]\left[\begin{array}{c}
\theta_{1} \\
\theta_{2} \\
-R
\end{array}\right]=\left[\begin{array}{c}
0 \\
0 \\
H L_{c}
\end{array}\right]
$$

From Eq. 9,

$$
R=\frac{H L_{c}^{2}}{8 E I_{c}}\left(\frac{1}{3}+\frac{1}{6 \lambda+1}\right)
$$

Since $R=\Delta_{H} / L_{c}$,

$$
\Delta_{H}=\frac{H L_{c}^{3}}{8 E I_{c}}\left(\frac{1}{3}+\frac{1}{6 \lambda+1}\right)
$$


Eq. 10 is to be used for the computation of the story drift for the fixed-base frame loaded under a lateral force $H$, as shown in Figure 1. Note that this equation considers the flexural deflections of the members only. Axial and shear deformations of the members have been neglected.

Similar to the derivation of Eq. 8 from the moment frame with fixed-base connections shown in Figure 1, Eq. 11 can be derived from the moment frame with pinned-base connections shown in Figure 2:

$$
\left[\begin{array}{ccc}
2 k_{1-2}+1.5 k_{1-3} & k_{1-2} & 1.5 k_{1-3} \\
k_{1-2} & 2 k_{1-2}+1.5 k_{2-4} & 1.5 k_{2-4} \\
1.5 k_{1-3} & 1.5 k_{2-4} & 1.5\left(k_{1-3}+k_{2-4}\right)
\end{array}\right]\left[\begin{array}{c}
\theta_{1} \\
\theta_{2} \\
-R
\end{array}\right]=\left[\begin{array}{c}
0 \\
0 \\
H L_{c}
\end{array}\right]
$$

where $k_{i-j}=2 E_{i-j} I_{i-j} / L_{i-j} ; \theta_{i}=$ rotation at joint $i ; R=\Delta H / L_{c}$.

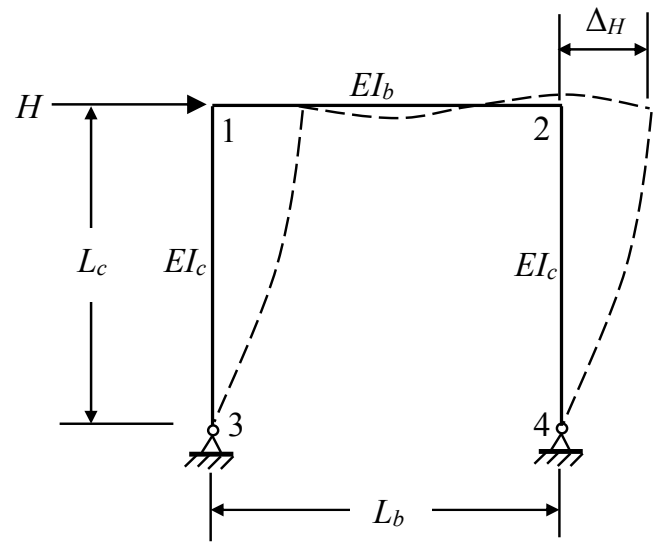

Notes:

$I_{c}=$ moment of inertia of column

$I_{b}=$ moment of inertia of beam

$L_{c}=$ column length

$L_{b}=$ beam length

$E=$ modulus of elasticity, constant for all members

$\Delta_{H}=$ story drift resulting from lateral force $H$

Figure 2. Typical Moment Frame with Ideal Pinned-Base Connections

Since the sizes and lengths of the two columns are identical, $k_{1-3}=k_{2-4}=2 E I_{c} / L_{c} . \quad$ Setting $\lambda=\left(I_{b} / L_{b}\right)$ $/\left(I_{c} / L_{c}\right)$, Eq. 11 can be rewritten as

$$
\frac{2 E I_{c}}{L_{c}}\left[\begin{array}{ccc}
2 \lambda+1.5 & \lambda & 1.5 \\
\lambda & 2 \lambda+1.5 & 1.5 \\
1.5 & 1.5 & 3
\end{array}\right]\left[\begin{array}{c}
\theta_{1} \\
\theta_{2} \\
-R
\end{array}\right]=\left[\begin{array}{c}
0 \\
0 \\
H L_{c}
\end{array}\right]
$$

From Eq. 12,

$$
R=\frac{H L_{c}^{2}}{6 E I_{c}}\left(1+\frac{1}{2 \lambda}\right)
$$

Since $R=\Delta_{H} / L_{c}$, 
$\Delta_{H}=\frac{H L_{c}^{3}}{6 E I_{c}}\left(1+\frac{1}{2 \lambda}\right)$

Eq. 13 is to be used for the computation of the story drift for the pinned-base frame loaded under a lateral force $H$, as shown in Figure 2. Also note that this equation considers the flexural deflections of the members only. Axial and shear deformations of the members have been neglected.

\section{EFFECTIVE LENGTH AND DIRECT ANALYSIS METHODS}

The 2010 AISC Specification addresses two major methods, the Effective Length and Direct Analysis Methods, for the calculation of the required strengths for the stability design of members and connections.

The Effective Length Method is valid so long as the ratio of second-order deflection to first-order deflection in all stories is equal to or less than 1.5 (that is: $B_{2}=\Delta_{\text {second-order }} / \Delta_{\text {first-order }} \leq 1.5$ ).

The Direct Analysis Method has the advantage of not having to calculate the effective length factor, $K$. This means that in designing compression members, the effective length factor is taken as 1.0. To accomplish this the Specification requires that a reduced axial and flexural stiffness shall be used for all elements contributing to the lateral load resistance of the structure to account for the influence of inelasticity and residual stresses on second-order effects. Note that the computation of the first-order interstory drift, $\Delta H$, in $R_{M} \frac{\sum H L}{\Delta_{H}}$, and, $\left(\delta_{x e}-\delta_{(x-1) e}\right)$, in $\frac{V_{x} h_{s x}}{\delta_{x e}-\delta_{(x-1) e}}$, respectively, in Section 5 uses the Effective Length Method. Therefore, the reduced axial and flexural stiffness in the members of the structure have been ignored.

However, the analysis using both methods shall consider flexural, shear and axial member deformations and all other component and connection deformations that contribute to displacements of the structure.

\section{COMPARISON OF EQUATIONS 1, 2, AND 3}

This section addresses the comparison of the $\sum \frac{\pi^{2} E I}{\left(K_{2} L\right)^{2}}, R_{M} \frac{\sum H L}{\Delta_{H}}$, and $\frac{V_{x} h_{s x}}{\delta_{x e}-\delta_{(x-1) e}}$ values in Eqs. 1,2 , and 3, respectively, for various column base conditions, which include the ideal fixed-base (a complete fixity, $G_{B}=0$ ) condition, the ideal pinned-base (a true friction-free pin, $G_{B}=\infty$ ) condition, the practical fixed-base $\left(G_{B}=1.0\right)$ condition, and the practical pinned-base $\left(G_{B}=10\right)$ condition. In this paper, $\left(P_{e}\right)_{1},\left(P_{e}\right)_{2}$, and $\left(P_{e}\right)_{3}$ represent the $\sum \frac{\pi^{2} E I}{\left(K_{2} L\right)^{2}}, R_{M} \frac{\sum H L}{\Delta_{H}}$, and $\frac{V_{x} h_{s x}}{\delta_{x e}-\delta_{(x-1) e}}$ values in Eqs. 1, 2, and 3, respectively.

\subsection{Ideal Fixed-Base Condition $\left(G_{B}=0\right)$}

Consider the frame shown in Figure 3(a) for the condition where $G_{A}=\left(I_{c} / L_{c}\right) /\left(I_{b} / L_{b}\right)=1.333$. From Eq. 6 , one has $K_{2}=1.205$. Therefore, the $\left(P_{e}\right)_{1}$ value in Eq. 1 can be computed as 
$\left(P_{e}\right)_{1}=2 \frac{\pi^{2} E I_{c}}{\left(1.205 L_{c}\right)^{2}}=13.59 \frac{E I_{c}}{L_{c}^{2}}=13.59 \frac{(29,000 \mathrm{ksi})\left(999 \mathrm{in}^{4}\right)}{(180 \mathrm{in} .)^{2}}=12,150 \mathrm{kips}(54040 \mathrm{kN})$

Note that the moment of inertia about the $x$-axis for W14×90, $I_{x}=999$ in. ${ }^{4}\left(41580 \mathrm{~cm}^{4}\right)[10]$.

Since $G_{A}=1.333, \lambda=\left(I_{b} / L_{b}\right) /\left(I_{c} / L_{c}\right)=1 / G_{A}=0.75$. From Eq. 10,

$$
\Delta_{H}=\frac{H L_{c}^{3}}{8 E I_{c}}\left(\frac{1}{3}+\frac{1}{4.5+1}\right)=0.0644\left(\frac{H L_{c}^{3}}{E I_{c}}\right)
$$

From which the $\left(P_{e}\right)_{2}$ value in Eq. 2 can be computed as

$$
\left(P_{e}\right)_{2}=R_{M} \frac{\sum H L_{c}}{\Delta_{H}}=0.85\left[\frac{H L_{c}}{0.0644\left(\frac{H L_{c}^{3}}{E I_{c}}\right)}\right]=13.2 \frac{E I_{c}}{L_{c}^{2}}=11,800 \mathrm{kips}(52490 \mathrm{kN})
$$

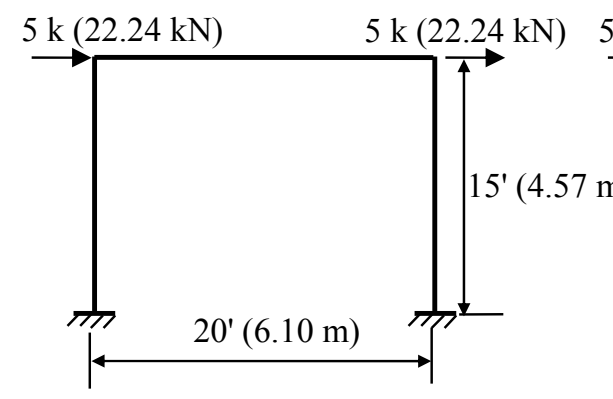

(a) $G_{A}=1.333$

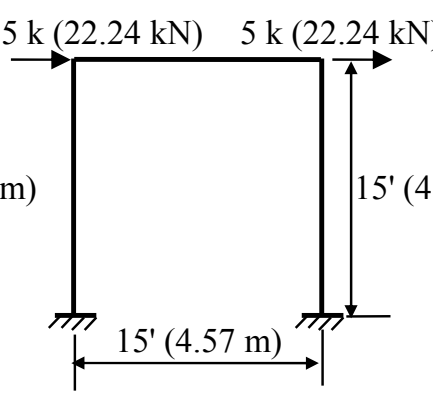

(b) $G_{A}=1.0$

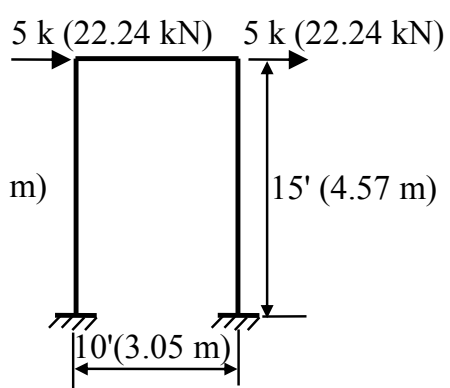

(c) $G_{A}=0.6667$

Notes: (1) All members are W14 $\times 90$.

(2) All members are bent about their $x$-axes due to the

Figure 3. Moment Frames with Ideal Fixed-Base Connections $\left(G_{B}=0\right)$

Table 1 summarizes and compares the computed $\left(P_{e}\right)_{1}$ and $\left(P_{e}\right)_{2}$ values in Eqs. 1 and 2 for $G_{A}=1.333$, 1 , and 0.6667 for the laterally loaded frames shown in Figure 3 for ideal fixed-base connections $\left(G_{B}=\right.$ $0)$. The results shown in Table 1 indicate that the computed $\left(P_{e}\right)_{1}$ values for Eq. 1 closely agree with the computed $\left(P_{e}\right)_{2}$ values for Eq. 2 . The differences between the $\left(P_{e}\right)_{1}$ and $\left(P_{e}\right)_{2}$ values vary from $1 \%$ for $G_{A}=0.6667$ to $3 \%$ for $G_{A}=1.333$. Note that the $\Delta_{H}$ values shown in Table 1 are derived from Eq. 10 , which considers the flexural deflections of the members only. Axial and shear deformations of the members have been neglected.

Table 2 also summarizes and compares the computed $\left(P_{e}\right)_{1}$ and $\left(P_{e}\right)_{2}$ values in Eqs. 1 and 2 for $G_{A}=$ 1.333, 1, and 0.6667 for the laterally loaded frames shown in Figure 3 for ideal fixed-base connections $\left(G_{B}=0\right)$. However, the $\Delta_{H}$ values shown in Table 2 are obtained by using the computer software SAP2000 [11], which considers the flexural deflections, as well as the axial and shear deformations, of the members. The results shown in Table 2 indicate that the computed $\left(P_{e}\right)_{1}$ values for Eq. 1 are all quite larger than the computed $\left(P_{e}\right)_{2}$ values for Eq. 2 . The differences between the $\left(P_{e}\right)_{1}$ and $\left(P_{e}\right)_{2}$ values vary from $16 \%$ for $G_{A}=1.333$ to $22 \%$ for $G_{A}=0.6667$. 
Table 1. Comparison of $\left(P_{e}\right)_{1}$ and $\left(P_{e}\right)_{2}$ for the Laterally Loaded Frames Shown in Figure 3 (Ideal fixed-base connections, $G_{B}=0$ )

\begin{tabular}{|c|c|c|c|c|c|c|}
\hline Figure & $G_{A}$ & $K_{2}$ & $\left(P_{e}\right)_{1}{ }^{\mathrm{a}}$ & $\Delta_{H}{ }^{\mathrm{b}}$ & $\left(P_{e}\right)_{2}{ }^{\mathrm{c}}$ & $\left(P_{e}\right)_{1}$ vs. $\left(P_{e}\right)_{2}$ \\
\hline 3(a) & 1.333 & 1.205 & $\begin{array}{l}13.59 \frac{E I_{c}}{L_{c}^{2}} \\
=12,150 \mathrm{kips} \\
(54040 \mathrm{kN})\end{array}$ & $\begin{array}{l}\frac{H L_{c}^{3}}{8 E I_{c}}\left(\frac{1}{3}+\frac{1}{5.5}\right) \\
=0.130 \mathrm{in} . \\
(0.330 \mathrm{~cm})\end{array}$ & $\begin{array}{l}13.20 \frac{E I_{c}}{L_{c}^{2}} \\
=11,800 \mathrm{kips} \\
(52490 \mathrm{kN})\end{array}$ & $\left(P_{e}\right)_{1}>\left(P_{e}\right)_{2}$ by $3 \%$ \\
\hline $3(\mathrm{~b})$ & 1.0 & 1.163 & $\begin{array}{l}14.59 \frac{E I_{c}}{L_{c}^{2}} \\
=13,050 \mathrm{kips} \\
(58040 \mathrm{kN})\end{array}$ & $\begin{array}{l}\frac{H L_{c}^{3}}{8 E I_{c}}\left(\frac{1}{3}+\frac{1}{7}\right) \\
=0.120 \mathrm{in} . \\
(0.305 \mathrm{~cm})\end{array}$ & $\begin{array}{l}14.28 \frac{E I_{c}}{L_{c}^{2}} \\
=12,770 \mathrm{kips} \\
(56800 \mathrm{kN})\end{array}$ & $\left(P_{e}\right)_{1}>\left(P_{e}\right)_{2}$ by $2 \%$ \\
\hline $3(\mathrm{c})$ & 0.6667 & 1.116 & $\begin{array}{l}15.86 \frac{E I_{c}}{L_{c}^{2}} \\
=14,180 \mathrm{kips} \\
(63070 \mathrm{kN})\end{array}$ & $\begin{array}{l}\frac{H L_{c}^{3}}{8 E I_{c}}\left(\frac{1}{3}+\frac{1}{10}\right) \\
=0.109 \mathrm{in} . \\
(0.277 \mathrm{~cm})\end{array}$ & $\begin{array}{l}15.69 \frac{E I_{c}}{L_{c}^{2}} \\
=14,030 \mathrm{kips} \\
(62410 \mathrm{kN})\end{array}$ & $\left(P_{e}\right)_{1}>\left(P_{e}\right)_{2}$ by $1 \%$ \\
\hline
\end{tabular}

${ }^{\mathrm{a}}\left(P_{e}\right)_{1}=\sum \frac{\pi^{2} E I}{\left(K_{2} L\right)^{2}}$ as shown in Eq. 1.

${ }^{\mathrm{b}}$ Only the flexural deflections of the members are considered for the computation of $\Delta_{H}$. ${ }^{\mathrm{c}}\left(P_{e}\right)_{2}=R_{M} \frac{\sum H L}{\Delta_{H}}$ as shown in Eq. 2.

Table 2. Comparison of $\left(P_{e}\right)_{1}$ and $\left(P_{e}\right)_{2}$ for the Laterally Loaded Frames Shown in Figure 3 (Ideal fixed-base connections, $G_{B}=0$ )

\begin{tabular}{|c|c|c|c|c|c|c|}
\hline Figure & $G_{A}$ & $K_{2}$ & $\left(P_{e}\right)_{1}{ }^{\mathrm{a}}$ & $\Delta_{H} \mathrm{~b}^{\mathrm{b}}$ & $\left(P_{e}\right)_{2}{ }^{\mathrm{c}}$ & $\left(P_{e}\right)_{1}$ vs. $\left(P_{e}\right)_{2}$ \\
\hline $3(\mathrm{a})$ & 1.333 & 1.205 & $\begin{array}{c}12,150 \mathrm{kips} \\
(54040 \mathrm{kN})\end{array}$ & $\begin{array}{c}0.146 \mathrm{in} . \\
(0.371 \mathrm{~cm})\end{array}$ & $\begin{array}{c}10,480 \mathrm{kips} \\
(46620 \mathrm{kN})\end{array}$ & $\left(P_{e}\right)_{1}>\left(P_{e}\right)_{2} \mathrm{by} 16 \%$ \\
\hline $3(\mathrm{~b})$ & 1.0 & 1.163 & $\begin{array}{c}13,050 \mathrm{kips} \\
(58040 \mathrm{kN})\end{array}$ & $\begin{array}{c}0.138 \mathrm{in} . \\
(0.351 \mathrm{~cm})\end{array}$ & $\begin{array}{c}11,090 \mathrm{kips} \\
(49330 \mathrm{kN})\end{array}$ & $\left(P_{e}\right)_{1}>\left(P_{e}\right)_{2}$ by $18 \%$ \\
\hline $3(\mathrm{c})$ & 0.6667 & 1.116 & $\begin{array}{c}14,180 \mathrm{kips} \\
(63070 \mathrm{kN})\end{array}$ & $\begin{array}{c}0.132 \mathrm{in} . \\
(0.335 \mathrm{~cm})\end{array}$ & $\begin{array}{c}11,590 \mathrm{kips} \\
(51550 \mathrm{kN})\end{array}$ & $\left(P_{e}\right)_{1}>\left(P_{e}\right)_{2}$ by $22 \%$ \\
& & & $(63 \%)$ \\
\hline
\end{tabular}

${ }^{\mathrm{a}}\left(P_{e}\right)_{1}=\sum \frac{\pi^{2} E I}{\left(K_{2} L\right)^{2}}$ as shown in Eq. 1.

${ }^{\mathrm{b}}$ The flexural deflections, as well as the axial and shear deformations, are considered for the computation of $\Delta_{H}$.

$$
{ }^{\mathrm{c}}\left(P_{e}\right)_{2}=R_{M} \frac{\sum H L}{\Delta_{H}} \text { as shown in Eq. } 2 .
$$

Table 3 summarizes and compares the computed $\left(P_{e}\right)_{1}$ and $\left(P_{e}\right)_{3}$ values in Eqs. 1 and 3 for $G_{A}=1.333$, 1 , and 0.6667 for the laterally loaded frames shown in Figure 3 for ideal fixed-base connections $\left(G_{B}=\right.$ $0)$. The $\left(\delta_{x e}-\delta_{(x-1) e}\right)$ values shown in Table 3 are obtained by using the computer software SAP2000, which considers the flexural deflections, as well as the axial and shear deformations, of the members. The results shown in Table 3 indicate that the computed $\left(P_{e}\right)_{1}$ values for Eq. 1 closely agree with the computed $\left(P_{e}\right)_{3}$ values for Eq. 3 . The differences between the $\left(P_{e}\right)_{1}$ and $\left(P_{e}\right)_{3}$ values are within $4 \%$. 
Table 3. Comparison of $\left(P_{e}\right)_{1}$ and $\left(P_{e}\right)_{3}$ for the Laterally Loaded Frames Shown in Figure 3 (Ideal fixed-base connections, $G_{B}=0$ )

\begin{tabular}{|c|c|c|c|c|c|c|}
\hline Figure & $G_{A}$ & $K_{2}$ & $\left(P_{e}\right)_{1}^{\mathrm{a}}$ & $\left(\delta_{x e}-\delta_{(x-1) e}\right)^{\mathrm{b}}$ & $\left(P_{e}\right)_{3}{ }^{\mathrm{c}}$ & $\left(P_{e}\right)_{1}$ VS. $\left(P_{e}\right)_{3}$ \\
\hline 3(a) & 1.333 & 1.205 & $\begin{array}{l}12,150 \mathrm{kips} \\
(54040 \mathrm{kN})\end{array}$ & $\begin{array}{c}0.146 \mathrm{in} . \\
(0.371 \mathrm{~cm})\end{array}$ & $\begin{array}{l}12,330 \mathrm{kips} \\
(54840 \mathrm{kN})\end{array}$ & $\left(P_{e}\right)_{1}<\left(P_{e}\right)_{3}$ by $1 \%$ \\
\hline 3(b) & 1.0 & 1.163 & $\begin{array}{l}\text { 13,050 kips } \\
(58040 \mathrm{kN})\end{array}$ & $\begin{array}{c}0.138 \mathrm{in} . \\
(0.351 \mathrm{~cm})\end{array}$ & $\begin{array}{l}13,040 \mathrm{kips} \\
(58000 \mathrm{kN})\end{array}$ & $\left(P_{e}\right)_{1} \approx\left(P_{e}\right)_{3}$ \\
\hline $3(\mathrm{c})$ & 0.6667 & 1.116 & $\begin{array}{l}\text { 14,180 kips } \\
(63070 \mathrm{kN})\end{array}$ & $\begin{array}{c}0.132 \text { in. } \\
(0.335 \mathrm{~cm})\end{array}$ & $\begin{array}{l}\text { 13,640 kips } \\
(60670 \mathrm{kN})\end{array}$ & $\left(P_{e}\right)_{1}>\left(P_{e}\right)_{3}$ by $4 \%$ \\
\hline
\end{tabular}

${ }^{\mathrm{a}}\left(P_{e}\right)_{1}=\sum \frac{\pi^{2} E I}{\left(K_{2} L\right)^{2}}$ as shown in Eq. 1.

${ }^{\mathrm{b}}$ The flexural deflections, as well as the axial and shear deformations, are considered for the computation of $\left(\delta_{x e}-\delta_{(x-1) e}\right)$.

${ }^{\mathrm{c}}\left(P_{e}\right)_{3}=\frac{V_{x} h_{s x}}{\delta_{x e}-\delta_{(x-1) e}}$ as shown in Eq. 3.

\subsection{Ideal Pinned-Base Condition $\left(G_{B}=\infty\right)$}

Table 4 summarizes and compares the computed $\left(P_{e}\right)_{1}$ and $\left(P_{e}\right)_{2}$ values in Eqs. 1 and 2 for $G_{A}=1.333$, 1 , and 0.6667 for the laterally loaded frames shown in Figure 4 for ideal pinned-base connections $\left(G_{B}\right.$ $=\infty)$. The results shown in Table 4 indicate that the computed $\left(P_{e}\right)_{1}$ values for Eq. 1 closely agree with the computed $\left(P_{e}\right)_{2}$ values for Eq. 2 . The differences between the values vary from $2 \%$ for $G_{A}=$ 0.6667 to $5 \%$ for $G_{A}=1.333$. Note that the computed $\Delta_{H}$ values shown in Table 4 are derived from Eq. 13, which considers the flexural deflections of the members only. Axial and shear deformations of the members have been neglected.

Table 4. Comparison of $\left(P_{e}\right)_{1}$ and $\left(P_{e}\right)_{2}$ for the Laterally Loaded Frames Shown in Figure 4 (Ideal pinned-base connections, $G_{B}=\infty$ )

\begin{tabular}{|c|c|c|c|c|c|c|}
\hline Figure & $G_{A}$ & $K_{2}$ & $\left(P_{e}\right)_{1}{ }^{\mathrm{a}}$ & $\Delta_{H}{ }^{\mathrm{b}}$ & $\left(P_{e}\right)_{2}{ }^{\mathrm{c}}$ & $\left(P_{e}\right)_{1}$ vs. $\left(P_{e}\right)_{2}$ \\
\hline $4(a)$ & 1.333 & 2.477 & $\begin{aligned} & 3.217 \frac{E I_{c}}{L_{c}^{2}} \\
&= 2,880 \mathrm{kips} \\
&(12810 \mathrm{kN})\end{aligned}$ & $\begin{array}{c}\frac{H L_{c}^{3}}{6 E I_{c}}\left(1+\frac{1}{1.5}\right) \\
=0.559 \mathrm{in} . \\
(1.420 \mathrm{~cm})\end{array}$ & $\begin{aligned} & 3.060 \frac{E I_{c}}{L_{c}^{2}} \\
&= 2,740 \mathrm{kips} \\
&(12190 \mathrm{kN})\end{aligned}$ & $\left(P_{e}\right)_{1}>\left(P_{e}\right)_{2}$ by $5 \%$ \\
\hline 4(b) & 1.0 & 2.366 & $\begin{array}{r}3.526 \frac{E I_{c}}{L_{c}^{2}} \\
=3,150 \mathrm{kips} \\
(14010 \mathrm{kN})\end{array}$ & $\begin{array}{l}\frac{H L_{c}^{3}}{6 E I_{c}}\left(1+\frac{1}{2}\right) \\
=0.503 \mathrm{in} . \\
(1.278 \mathrm{~cm})\end{array}$ & $\begin{array}{r}3.400 \frac{E I_{c}}{L_{c}^{2}} \\
=3,040 \mathrm{kips} \\
(13520 \mathrm{kN})\end{array}$ & $\left(P_{e}\right)_{1}>\left(P_{e}\right)_{2}$ by $4 \%$ \\
\hline $4(\mathrm{c})$ & 0.6667 & 2.251 & $\begin{aligned} & 3.896 \frac{E I_{c}}{L_{c}^{2}} \\
&= 3,480 \mathrm{kips} \\
&(15480 \mathrm{kN})\end{aligned}$ & $\begin{array}{l}\frac{H L_{c}^{3}}{6 E I_{c}}\left(1+\frac{1}{3}\right) \\
=0.447 \mathrm{in} . \\
(1.135 \mathrm{~cm})\end{array}$ & $\begin{array}{r}3.825 \frac{E I_{c}}{L_{c}^{2}} \\
=3,420 \mathrm{kips} \\
(15210 \mathrm{kN})\end{array}$ & $\left(P_{e}\right)_{1}>\left(P_{e}\right)_{2}$ by $2 \%$ \\
\hline
\end{tabular}

${ }^{\mathrm{a}}\left(P_{e}\right)_{1}=\sum \frac{\pi^{2} E I}{\left(K_{2} L\right)^{2}}$ as shown in Eq. 1.

${ }^{\mathrm{b}}$ Only the flexural deflections of the members are considered for the computation of $\Delta_{H}$.

${ }^{\mathrm{c}}\left(P_{e}\right)_{2}=R_{M} \frac{\sum H L}{\Delta_{H}}$ as shown in Eq. 2. 


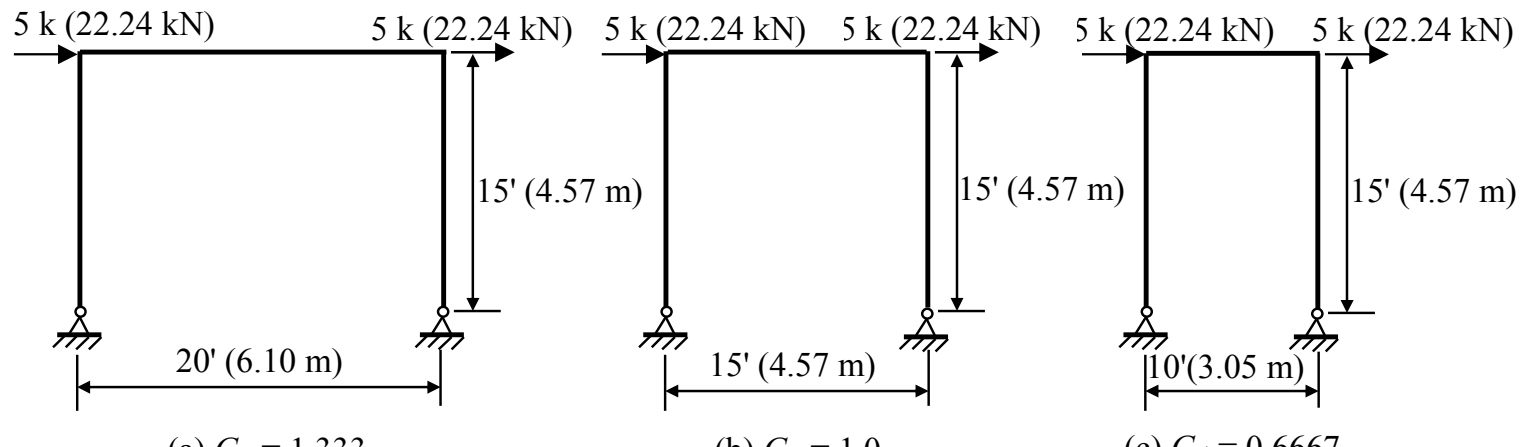

(a) $G_{A}=1.333$

(b) $G_{A}=1.0$

(c) $G_{A}=0.6667$

Notes: (1) All members are W14 $\times 90$.

(2) All members are bent about their $\mathrm{x}$-axes due to the applied

Figure 4. Moment Frames with Ideal Pinned-Base Connections $\left(G_{B}=\infty\right)$

Table 5 also summarizes and compares the computed $\left(P_{e}\right)_{1}$ and $\left(P_{e}\right)_{2}$ values in Eqs. 1 and 2 for $G_{A}=$ $1.333,1$, and 0.6667 for the laterally loaded frames shown in Figure 4 for ideal pinned-base connections $\left(G_{B}=\infty\right)$. However, the $\Delta_{H}$ values shown in Table 5 are obtained by using the computer software SAP2000, which considers the flexural deflections, as well as the axial and shear deformations, of the members. The results shown in Table 5 indicate that the computed $\left(P_{e}\right)_{1}$ values for Eq. 1 are all quite larger than the computed $\left(P_{e}\right)_{2}$ values for Eq. 2 . The differences between the values vary from $12 \%$ for $G_{A}=1.333$ to $16 \%$ for $G_{A}=0.6667$.

Table 5. Comparison of $\left(P_{e}\right)_{1}$ and $\left(P_{e}\right)_{2}$ for the Laterally Loaded Frames Shown in Figure 4 (Ideal pinned-base connections, $G_{B}=\infty$ )

\begin{tabular}{|c|c|c|c|c|c|c|}
\hline Figure & $G_{A}$ & $K_{2}$ & $\left(P_{e}\right)_{1}{ }^{\mathrm{a}}$ & $\Delta_{H}{ }^{\mathrm{b}}$ & $\left(P_{e}\right)_{2}{ }^{\mathrm{c}}$ & $\left(P_{e}\right)_{1}$ vs. $\left(P_{e}\right)_{2}$ \\
\hline $4(\mathrm{a})$ & 1.333 & 2.477 & $\begin{array}{c}2,880 \mathrm{kips} \\
(12810 \mathrm{kN})\end{array}$ & $\begin{array}{c}0.595 \mathrm{in} . \\
(1.511 \mathrm{~cm})\end{array}$ & $\begin{array}{c}2,570 \mathrm{kips} \\
(11430 \mathrm{kN})\end{array}$ & $\left(P_{e}\right)_{1}>\left(P_{e}\right)_{2}$ by $12 \%$ \\
\hline $4(\mathrm{~b})$ & 1.0 & 2.366 & $\begin{array}{r}3,150 \mathrm{kips} \\
(14010 \mathrm{kN})\end{array}$ & $\begin{array}{c}0.547 \mathrm{in} . \\
(1.389 \mathrm{~cm})\end{array}$ & $\begin{array}{c}2,800 \mathrm{kips} \\
(12450 \mathrm{kN})\end{array}$ & $\left(P_{e}\right)_{1}>\left(P_{e}\right)_{2}$ by $13 \%$ \\
& & & $\begin{array}{r}3,480 \mathrm{kips} \\
(15480 \mathrm{kN})\end{array}$ & $\begin{array}{c}0.510 \mathrm{in} . \\
(1.295 \mathrm{~cm})\end{array}$ & $\begin{array}{c}3,000 \mathrm{kips} \\
(13340 \mathrm{kN})\end{array}$ & $\left(P_{e}\right)_{1}>\left(P_{e}\right)_{2}$ by $16 \%$ \\
\hline 4(c) & 0.6667 & 2.251 & & \\
\end{tabular}

${ }^{\mathrm{a}}\left(P_{e}\right)_{1}=\sum \frac{\pi^{2} E I}{\left(K_{2} L\right)^{2}}$ as shown in Eq. 1.

${ }^{\mathrm{b}}$ The flexural deflections, as well as the axial and shear deformations, are considered for the computation of $\Delta H$.

${ }^{\mathrm{c}}\left(P_{e}\right)_{2}=R_{M} \frac{\sum H L}{\Delta_{H}}$ as shown in Eq. 2.

Table 6 summarizes and compares the computed $\left(P_{e}\right)_{1}$ and $\left(P_{e}\right)_{3}$ values in Eqs. 1 and 3 for $G_{A}=1.333$, 1 , and 0.6667 for the laterally loaded frames shown in Figure 4 for ideal pinned-base connections $\left(G_{B}\right.$ $=\infty)$. The $\left(\delta_{x e}-\delta_{(x-1) e}\right)$ values shown in Table 6 are obtained by using the computer software SAP2000, which considers the flexural deflections, as well as the axial and shear deformations, of the members. The results shown in Table 6 indicate that the computed $\left(P_{e}\right)_{1}$ values for Eq. 1 closely agree with the computed $\left(P_{e}\right)_{3}$ values for Eq. 3 . The differences between the values vary from $1 \%$ for $G_{A}=$ 0.6667 to $5 \%$ for $G_{A}=1.333$. 
Table 6. Comparison of $\left(P_{e}\right)_{1}$ and $\left(P_{e}\right)_{3}$ for the Laterally Loaded Frames Shown in Figure 4 (Ideal pinned-base connections, $G_{B}=\infty$ )

\begin{tabular}{|l|l|c|c|c|c|c|}
\hline Figure & $G_{A}$ & $K_{2}$ & $\left(P_{e}\right)_{1}{ }^{\mathrm{a}}$ & $\left(\delta_{x e}-\delta_{(x-1) e}\right)^{\mathrm{b}}$ & \multicolumn{1}{|c|}{$\left(P_{e}\right)_{3}{ }^{\mathrm{c}}$} & \multicolumn{1}{c|}{$\left(P_{e}\right)_{1}$ vs. $\left(P_{e}\right)_{3}$} \\
\hline $4(\mathrm{a})$ & 1.333 & 2.477 & $2,880 \mathrm{kips}$ & $0.595 \mathrm{in}$. & $3,030 \mathrm{kips}$ & $\left(P_{e}\right)_{1}<\left(P_{e}\right)_{3}$ by $5 \%$ \\
& & & $(12810 \mathrm{kN})$ & $(1.511 \mathrm{~cm})$ & $(13470 \mathrm{kN})$ & \\
\hline $4(\mathrm{~b})$ & 1.0 & 2.366 & $\begin{array}{c}3,150 \mathrm{kips} \\
(14010 \mathrm{kN})\end{array}$ & $\begin{array}{c}0.547 \mathrm{in} . \\
(1.389 \mathrm{~cm})\end{array}$ & $\begin{array}{l}3,290 \mathrm{kips} \\
(14630 \mathrm{kN})\end{array}$ & $\begin{array}{l}\left(P_{e}\right)_{1}<\left(P_{e}\right)_{3} \text { by } 4 \\
\%\end{array}$ \\
\hline $4(\mathrm{c})$ & 0.6667 & 2.251 & $\begin{array}{c}3,480 \mathrm{kips} \\
(15480 \mathrm{kN})\end{array}$ & $\begin{array}{c}0.510 \mathrm{in} . \\
(1.295 \mathrm{~cm})\end{array}$ & $\begin{array}{l}3,530 \mathrm{kips} \\
(15700 \mathrm{kN})\end{array}$ & $\begin{array}{l}\left(P_{e}\right)_{1}<\left(P_{e}\right)_{3} \text { by } 1 \\
\%\end{array}$ \\
\hline
\end{tabular}

${ }^{\mathrm{a}}\left(P_{e}\right)_{1}=\sum \frac{\pi^{2} E I}{\left(K_{2} L\right)^{2}}$ as shown in Eq. 1.

${ }^{\mathrm{b}}$ The flexural deflections, as well as the axial and shear deformations, are considered for the computation of $\left(\delta_{x e}-\delta_{(x-1) e}\right)$.

${ }^{\mathrm{c}}\left(P_{e}\right)_{3}=\frac{V_{x} h_{s x}}{\delta_{x e}-\delta_{(x-1) e}}$ as shown in Eq. 3.

\subsection{Practical Fixed-Base Condition $\left(G_{B}=1\right)$}

In order to achieve the practical fixed-base condition with $G_{B}=1$, the computer model of the frame shown in Figure 3(b) is modified to become the frame shown in Figure 5 by adding a base beam W14 $\times 90$ to connect the bases of the W14 $\times 90$ columns, as well as by changing the fixed bases to pinned bases. Note that both ends of the added base beam are rigidly connected to the bottom ends of the columns, while the newly added pinned bases are located right below the new rigid connections at the bottom ends of the columns. Referring Figure 5, $G_{B}$ can be computed as

$$
G_{B}=\frac{\sum\left(I_{c} / L_{c}\right)}{\sum\left(I_{b} / L_{b}\right)}=\frac{\left(999 \mathrm{in} .^{4} / 180 \mathrm{in} .\right)}{\left(999 \mathrm{in} .^{4} / 180 \mathrm{in} .\right)}\left[=\frac{\left(41580 \mathrm{~cm}^{4} / 457 \mathrm{~cm}\right)}{\left(41580 \mathrm{~cm}^{4} / 457 \mathrm{~cm}\right)}\right]=1
$$

Note that $I_{b}$ and $L_{b}$ shown in the above equation are the moment of inertia (about the $x$-axis) and the length of the base beam, while $I_{c}$ and $L_{c}$ are the moment of inertia (about the $x$-axis) and the length of the column.

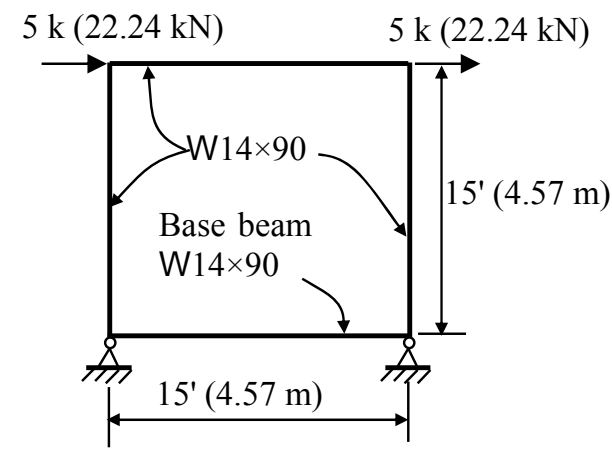

Note: All members are bent about their x-axes due to the applied forces.

Figure 5. Moment Frame with Modified Base Stiffness for the Practical Fixed-Base Condition with $G_{B}=1$ 
Table 7 summarizes and compares the computed $\left(P_{e}\right)_{1}$ and $\left(P_{e}\right)_{2}$ values in Eqs. 1 and 2 for the laterally loaded frame with $G_{A}=1$ and $G_{B}=1$ as shown in Figure 5. Note that the $\Delta_{H}$ value shown in Table 7 is obtained by using the computer software SAP2000, which considers the flexural deflections, as well as the axial and shear deformations, of the members. The results shown in Table 7 indicate that the computed $\left(P_{e}\right)_{1}$ value for Eq. 1 is about $25 \%$ larger than the computed $\left(P_{e}\right)_{2}$ value for Eq. 2.

Table 7. Comparison of $\left(P_{e}\right)_{1}$ and $\left(P_{e}\right)_{2}$ for the Laterally Loaded Frames Shown in Figure 5 (Practical fixed-base connections)

\begin{tabular}{|c|c|c|c|c|c|c|}
\hline$G_{A}$ & $G_{B}$ & $K_{2}$ & $\left(P_{e}\right)_{1}{ }^{\mathrm{a}}$ & $\Delta_{H}{ }^{\mathrm{b}}$ & $\left(P_{e}\right)_{2}{ }^{\mathrm{c}}$ & $\left(P_{e}\right)_{1}$ vs. $\left(P_{e}\right)_{2}$ \\
\hline 1.0 & 1.0 & 1.342 & $9,800 \mathrm{kips}$ & $0.196 \mathrm{in}$. & $7,810 \mathrm{kips}$ & $\left(P_{e}\right)_{1}>\left(P_{e}\right)_{2}$ by $25 \%$ \\
& & & $(43590 \mathrm{kN})$ & $(0.498 \mathrm{~cm})$ & $(34740 \mathrm{kN})$ & \\
\hline
\end{tabular}

${ }^{\mathrm{a}}\left(P_{e}\right)_{1}=\sum \frac{\pi^{2} E I}{\left(K_{2} L\right)^{2}}$ as shown in Eq. 1.

b The flexural deflections, as well as the axial and shear deformations, are considered for the computation of $\Delta_{H}$.

$$
{ }^{\mathrm{c}}\left(P_{e}\right)_{2}=R_{M} \frac{\sum H L}{\Delta_{H}} \text { as shown in Eq. } 2 .
$$

Table 8 summarizes and compares the computed $\left(P_{e}\right)_{1}$ and $\left(P_{e}\right)_{3}$ values in Eqs. 1 and 3 for the laterally loaded frame with $G_{A}=1$ and $G_{B}=1$ as shown in Figure 5. Note that the $\left(\delta_{x e}-\delta_{(x-1) e}\right)$ value shown in Table 8 is obtained by using the computer software SAP2000, which considers the flexural deflections, as well as the axial and shear deformations, of the members. The results shown in Table 8 indicate that the computed $\left(P_{e}\right)_{1}$ value for Eq. 1 is about $7 \%$ larger than the computed $\left(P_{e}\right)_{3}$ value for Eq. 3.

Table 8. Comparison of $\left(P_{e}\right)_{1}$ and $\left(P_{e}\right)_{3}$ for the Laterally Loaded Frames Shown in Figure 5 (Practical fixed-base connections)

\begin{tabular}{|c|c|c|c|c|c|c|}
\hline$G_{A}$ & $G_{B}$ & $K_{2}$ & $\left(P_{e}\right)_{1}{ }^{\mathrm{a}}$ & $\left(\delta_{x e}-\delta_{(x-1) e}\right)^{\mathrm{b}}$ & $\left(P_{e}\right)_{3}{ }^{\mathrm{c}}$ & $\left(P_{e}\right)_{1}$ vs. $\left(P_{e}\right)_{3}$ \\
\hline 1.0 & 1.0 & 1.342 & $9,800 \mathrm{kips}$ & $0.196 \mathrm{in}$. & $9,180 \mathrm{kips}$ & $\left(P_{e}\right)_{1}>\left(P_{e}\right)_{3}$ by 7 \\
& & & $(43590 \mathrm{kN})$ & $(0.498 \mathrm{~cm})$ & $(40830 \mathrm{kN})$ & $\%$ \\
\hline
\end{tabular}

${ }^{\mathrm{a}}\left(P_{e}\right)_{1}=\sum \frac{\pi^{2} E I}{\left(K_{2} L\right)^{2}}$ as shown in Eq. 1.

${ }^{\mathrm{b}}$ The flexural deflections, as well as the axial and shear deformations, are considered for the computation of $\left(\delta_{x e}-\delta_{(x-1) e}\right)$.

$$
{ }^{\mathrm{c}}\left(P_{e}\right)_{3}=\frac{V_{x} h_{s x}}{\delta_{x e}-\delta_{(x-1) e}} \text { as shown in Eq. } 3 .
$$

\subsection{Practical Pinned-Base Condition $\left(G_{B}=10\right)$}

In order to achieve the practical fixed-base condition with $G_{B}=10$, the computer model of the frame shown in Figure 4(b) is modified to become the frame shown in Figure 6 by adding a base beam W $8 \times 28$ to connect the bases of the W $14 \times 90$ columns. Note that both ends of the added base beam are rigidly connected to the bottom ends of the columns, while the pinned bases are located right below the new rigid connections at the bottom ends of the columns. Referring Figure 6 , the $G_{B}$ can be computed as 


$$
G_{B}=\frac{\sum\left(I_{c} / L_{c}\right)}{\sum\left(I_{b} / L_{b}\right)}=\frac{\left(999 \text { in. }^{4} / 180 \text { in. }\right)}{\left(98 \text { in. }^{4} / 180 \mathrm{in} .\right)}\left[=\frac{\left(41580 \mathrm{~cm}^{4} / 457 \mathrm{~cm}\right)}{\left(4080 \mathrm{~cm}^{4} / 457 \mathrm{~cm}\right)}\right] \approx 10
$$

Note that $I_{b}$ and $L_{b}$ shown in the above equation are the moment of inertia (about the $x$-axis) and the length of the base beam, while $I_{c}$ and $L_{c}$ are the moment of inertia (about the $x$-axis) and the length of the column.

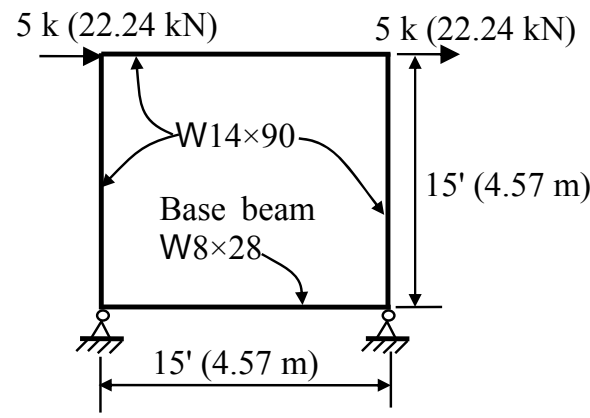

Note: All members are bent about their x-axes due to the applied forces.

Figure 6. Moment Frame with Modified Base Stiffness for the Practical Pinned-Base Condition with $G_{B}=10$

Table 9 summarizes and compares the computed $\left(P_{e}\right)_{1}$ and $\left(P_{e}\right)_{2}$ values in Eqs. 1 and 2 for the laterally loaded frame with $G_{A}=1$ and $G_{B}=10$ as shown in Figure 6. Note that the $\Delta_{H}$ value shown in Table 9 is obtained by using the computer software SAP2000, which considers the flexural deflections, as well as the axial and shear deformations, of the members. The results shown in Table 9 indicate that the computed $\left(P_{e}\right)_{1}$ value for Eq. 1 is about $22 \%$ larger than the computed $\left(P_{e}\right)_{2}$ value for Eq. 2.

Table 9. Comparison of $\left(P_{e}\right)_{1}$ and $\left(P_{e}\right)_{2}$ for the Laterally Loaded Frames Shown in Figure 6 (Practical pinned-base connections)

\begin{tabular}{|c|c|c|c|c|c|c|}
\hline$G_{A}$ & $G_{B}$ & $K_{2}$ & $\left(P_{e}\right)_{1}{ }^{\mathrm{a}}$ & $\Delta_{H}{ }^{\mathrm{b}}$ & $\left(P_{e}\right)_{2}{ }^{\mathrm{c}}$ & $\left(P_{e}\right)_{1}$ vs. $\left(P_{e}\right)_{2}$ \\
\hline 1.0 & 10 & 1.910 & $4,840 \mathrm{kips}$ & $0.384 \mathrm{in}$. & $3,980 \mathrm{kips}$ & $\left(P_{e}\right)_{1}>\left(P_{e}\right)_{2}$ by $22 \%$ \\
& & & $(21530 \mathrm{kN})$ & $(0.975 \mathrm{~cm})$ & $(17700 \mathrm{kN})$ & \\
\hline
\end{tabular}

${ }^{\mathrm{a}}\left(P_{e}\right)_{1}=\sum \frac{\pi^{2} E I}{\left(K_{2} L\right)^{2}}$ as shown in Eq. 1.

${ }^{\mathrm{b}}$ The flexural deflections, as well as the axial and shear deformations, are considered for the computation of $\Delta H$.

$$
{ }^{\mathrm{c}}\left(P_{e}\right)_{2}=R_{M} \frac{\sum H L}{\Delta_{H}} \text { as shown in Eq. } 2 .
$$

Table 10 summarizes and compares the computed $\left(P_{e}\right)_{1}$ and $\left(P_{e}\right)_{3}$ values in Eqs. 1 and 3 for the laterally loaded frame with $G_{A}=1$ and $G_{B}=10$ as shown in Figure 6. Note that the $\left(\delta_{x e}-\delta_{(x-1) e}\right)$ value shown in Table 10 is obtained by using the computer software SAP2000, which considers the flexural deflections, as well as the axial and shear deformations, of the members. The results shown in Table 10 indicate that the computed $\left(P_{e}\right)_{1}$ value for Eq. 1 is about $3 \%$ larger than the computed $\left(P_{e}\right) 3$ value for Eq. 3. 
Table 10. Comparison of $\left(P_{e}\right)_{1}$ and $\left(P_{e}\right)_{3}$ for the Laterally Loaded Frames Shown in Figure 6 (Practical pinned-base connections)

\begin{tabular}{|c|c|c|c|c|c|c|}
\hline$G_{A}$ & $G_{B}$ & $K_{2}$ & $\left(P_{e}\right)_{1}{ }^{\mathrm{a}}$ & $\left(\delta_{x e}-\delta_{(x-1) e}\right)^{\mathrm{b}}$ & $\left(P_{e}\right)_{3}{ }^{\mathrm{c}}$ & $\left(P_{e}\right)_{1}$ vs. $\left(P_{e}\right)_{3}$ \\
\hline 1.0 & 10 & 1.910 & $4,840 \mathrm{kips}$ & $0.384 \mathrm{in}$. & $4,690 \mathrm{kips}$ & $\left(P_{e}\right)_{1}>\left(P_{e}\right)_{3}$ by $3 \%$ \\
& & & $(21530 \mathrm{kN})$ & $(0.975 \mathrm{~cm})$ & $(20860 \mathrm{kN})$ & \\
\hline
\end{tabular}

${ }^{\mathrm{a}}\left(P_{e}\right)_{1}=\sum \frac{\pi^{2} E I}{\left(K_{2} L\right)^{2}}$ as shown in Eq. 1 .

$\mathrm{b}$ The flexural deflections, as well as the axial and shear deformations, are considered for the computation of $\left(\delta_{x e}-\delta_{(x-1) e}\right)$.

${ }^{\mathrm{c}}\left(P_{e}\right)_{3}=\frac{V_{x} h_{s x}}{\delta_{x e}-\delta_{(x-1) e}}$ as shown in Eq. 3 .

\section{DISCUSSION AND CONCLUSION}

The approaches that have been commonly used by structural engineers for the computation of the sidesway magnification factor for the design of columns in steel moment frames subjected to the P- $\Delta$ effect are the column-lateral-buckling-strength approach (suggested by the 2005 AISC Specification for Structural Steel Buildings), the story-lateral-stiffness approach (suggested by the ASCE/SEI 7-10 Minimum Design Loads for Buildings and Other Structures), and the modified-story-lateral-stiffness approach (suggested by the 2005 and 2010 AISC Specification for Structural Steel Buildings). The column-lateral-buckling-strength approach involves the computation of the elastic story sidesway buckling resistance, the story-lateral-stiffness approach involves the computation of the elastic analysis of the first-order interstory drift due to lateral forces, and the modified-story-lateral-stiffness approach involves the computation of the first-order interstory drift using the lateral stiffness modification coefficient, $R_{M}$, for moment-frame systems.

The story-lateral-stiffness approach has been recognized as an accurate approach for low- or medium-rise rigid frames, while the column-lateral-buckling-strength approach has been classified as a very approximate approach. Nevertheless, the results of the study conducted in this paper are that (1) the sidesway magnification factor derived from the column-lateral-buckling-strength approach closely agrees with that derived from the modified story-lateral-stiffness approach if only the flexural deflections are considered in the frame analysis for the computation of the interstory drifts of the frame and (2) the sidesway magnification factor derived from the column-lateral-buckling-strength approach closely agrees with that derived from the story-lateral-stiffness approach if the flexural deflections, as well as the shear and axial deformations, are considered in the frame analysis for the computation of the interstory drifts of the frame.

Since the column-lateral-buckling-strength approach is a hand-calculated approach, it can be used rapidly and practically to confirm the accuracy and validity of the results derived from the story-lateral-stiffness approach, which is usually carried out with computer software for the computation of sidesway magnification factors for steel moment frames subjected to the P- $\Delta$ effect.

\section{NOTATION}

The following symbols are used in this paper:

$B_{2} \quad=$ sidesway amplifier

$E \quad=\quad$ the modulus of elasticity of steel, 29,000 ksi (200 $000 \mathrm{MPa})$ 
$G \quad=\quad$ the restraint factor at the column end

$H=$ the story shear produced by the lateral forces used to compute $\Delta_{H}$

$\sum H=$ the story shear produced by the lateral forces used to compute $\Delta_{H}$

$h_{s x}=$ the story height below level $x$

$I=$ the moment of inertia in the plane of bending

$I_{b} \quad=$ moment of inertia of beam

$I_{c}=$ moment of inertia of column

$K_{2}=$ the effective length factor in the plane of bending, based on sidesway buckling

$L=$ the story height

$L_{b} \quad=$ the beam length

$L_{c} \quad=$ the column length

$P_{m f}=$ the total vertical load in columns in the story that are part of moment frames

$\sum P_{n t}=$ the total vertical load supported by the story

$P_{\text {story }}=$ the total vertical load supported by the story

$P_{x}=$ the total vertical design load at and above level $x$

$R_{M}=0.85$ for moment-frame systems

$V_{x} \quad=\quad$ the shear force acting between levels $x$ and $x$-1

$\alpha \quad=1.00$ for LRFD

$\Delta_{H} \quad=$ the first-order interstory drift resulting from lateral forces

$\delta_{x e} \quad=$ the displacement at level $x$ by a first-order elastic analysis

$\delta_{(x-1) e}=$ the displacement at level $x$ - 1 by a first-order elastic analysis

$\theta_{i} \quad=$ rotation at joint $i$

\section{REFERENCES}

[1] Gaiotti, R. and Smith, B.S., "P-delta Analysis for Building Structures", Journal of Structural Engineering, ASCE, 1989, Vol. 115, No. 4, pp. 755-770.

[2] AISC, "Specification for Structural Steel buildings", American Institute of Steel Construction, Inc., Chicago, IL., 2005.

[3] ASCE, "ASCE/SEI 7-10 Minimum Design Loads for Buildings and Other Structures", American Society of Civil Engineers, Reston, Virginia, 2010.

[4] AISC, "Specification for Structural Steel Buildings", American Institute of Steel Construction, Inc., Chicago, IL., 2010.

[5] Timoshenko, S.P. and Gere, J.M., "Theory of Elastic Stability", $2^{\text {nd }}$ Ed., McGraw-Hill Book Co., New York, N.Y., 1961.

[6] Salmon, C.G., Johnson, J.E. and Malhas, F.A., "Steel Structures, Design and Behavior", 5 Ed., Pearson Prentice Hall, Upper Saddle River, N.J., 2009.

[7] Dumonteil, P., "Simple Equations for Effective Length Factors", Engineering Journal, AISC, $3^{\text {rd }}$ quarter, 1992, pp. 111-115.

[8] AISC, "Steel Design Guide 1 - Base Plate and Anchor Rod Design", 2 ${ }^{\text {nd }}$ Ed., American Institute of Steel Construction, Chicago, IL., 2010.

[9] Hsiao, J.K., "Computation of Fundamental Periods for Moment Frames Using a Hand-calculated Approach”, Electronic Journal of Structural Engineering, 2009, Vol. 9, pp. $16-28$.

[10] AISC, "Steel Construction Manual”, $14^{\text {th }}$ Ed., American Institute of Steel Construction, Inc., Chicago, IL. 2011.

[11] SAP2000 Educational, "SAP2000 Manuals", Computers and Structures, Inc., Berkeley, CA., 1997. 